\title{
ERA FINTECH: PELUANG DAN TANTANGAN BAGI EKONOMI SYARIAH
}

\author{
Rokhmat Subagiyo \\ Jurusan Ekonomi Syariah IAIN Tulungagung \\ Email: rokhmatsubagyo@iain-tulungagung.ac.id
}

\begin{abstract}
Changes in digital technology occur very quickly because of the industrial revolution 4.0. Human behavior has changed in accessing financial services or FinTech. Modern online businesses replace traditional businesses. Indonesia as one of the prima donna to develop FinTech. The Islamic financial industry is more stable and stronger to survive than the conventional financial industry. FinTech sharia opportunities are still wide open because it provides solutions for needs that cannot be served by conventional financial services. The results of the study include: (1) FinTech Sharia is able to realize the transparency of financial activities; (2) creating opportunities for customers both households and businesses to access sharia financial services; (3) providing sharia investment opportunities; (4) fintech has the potential to pose risks to consumers. Recommendation given: Islamic economics is important to answer the challenges of FinTech by issuing products or policies that are in accordance with the development of FinTech and Islamic principles.
\end{abstract}

Keywords: FinTech Syariah, Industrial Revolution 4.0, Financial services 


\section{Pendahuluan}

Gelombang revolusi industri 4.0 menyebabkan perubahan yang begitu cepat dalam teknologi digital. Kemajuan ini dimulai dari tersedianya komputer yang canggih, robot pintar, mobil tanpa pengendara, telepon smart dan berbagai aneka inustri yang lebih mengedapankan fungsi dari otak manusia. Perubahan yang cepat dipandang sebagai disrupsi inovatif yang merubah dunia melalui cara-cara interaksi sosial dan relasi pribadi atau individu. Industri-industri yang sudah ada dan mapan (seatle) dirusak (creative destruction) dengan berdirinya jenis-jenis industri baru, pemain baru, tipe bisnis baru dan value proposition baru. Kemajuan digitalisasi telah berjalan sangat cepat mengalahkan sektorsektor lainnya.

Era digital merubah perilaku atau kebiasaan manusia untuk mengakses informasi dan layanan eletronik yang berbasis teknologi. Telepon seluler atau smartphone memenuhi kebutuhan informasi dan aneka turunannya terhadap manusia. Sektor ekonomi berkembang lebih cepat, efisien dan canggih sehingga lebih maju dibandingkan sektor lainnya. Jumlah manusia yang mempunyai telepon genggam lebih banyak daripada mereka yang mempunyai akses terhadap pelayanan listrik atau air bersih.

Inovasi teknologi keuangan bagi sektor keuangan sudah lama terjadi, karena keduanya mempunyai riwayat yang panjang berkaitan antara teknologi keuangan (financial techology) atau lebih popular disebut FinTech, bagi industri keuangan jasa keuangan merupakan barang lama. Adanya smartphone merupakan wujud perkembangan fintech yang luar biasa cepat, ditandai munculnya teknologi bisnis keuangan yang mampu merubah perilaku bisnis pada masyarakat saat melakukan transaksi. Era digital mengubah kebiasaan manusia untuk mengakses informasi dan layanan elektronik. Sektor perekonomian mengalami perkembangan yang lebih efisien dan efektif.

Perubahan teknologi yang begitu cepat merambah ke Indonesia berimplikasi terhadap bisnis e-commerce, bisnis online, transportasi daring dan sebagainya yang menjadi bagian dari teknologi keuangan mulai tumbuh menggantikan bisnis tradisional. Dengan demikian penting untuk mengkaji perkembangan teknologi keuangan. Jaringan internet yang mudah diakses oleh orang, dari tempat manapun dan waktu kapan pun memaksa perilaku orang berbisnis agar tetap bertahan hidup, terus 
melakukan kreatitifitas dan inovasi. Kesimpulan yang dibisa diambil perubahan yang amat cepat berdampak negatif, yakni merugikan bagi kondisi ekonomi dan sosial.

Teknologi keuangan atau fintech merupakan perkembangan teknologi yang dikombinasikan dengan sektor keuangan atau financial yang terdapat pada lembaga perbankan. Dengan demikian diharapkan dapat mempermudah proses transaksi keuangan yang lebih praktis, aman dan modern, dengan layanan keuangan berbasis layanan digital yang berkembang di Indonesia, seperti payment channel system, digital banking, online digital insurance.

Sebagai salah satu negara yang menjadi primadona untuk pengembangan fintech adalah Indonesia ${ }^{1}$. PT. Gojek Indonesia memberikan layanan e-payment sejak 2016, menjadi layanan empat (4) besar bersama layanan yang dipunyai perbankan konvensional ${ }^{2}$. Layanan ini berkembang cepat sekali dan tetap dalam kondisi yang baik serta stabil dan sipa bersaing dengan layanan pesaingnya. Dari sisi teknologi, layanan keuangan di Indonesia masih terbuka luas, sehingga berkesempatan besar untuk dikelola dan dikembangkan. Potensi ini harus diambil oleh Indonesia, apabila tidak ingin kalah dengan negara lainnya, seperti Singapura, Malaysia, Brunei dan negara ASEAN lainnya.

Industri keuangan syariah lahirnya yang belakangan daripada industri keuangan konvensional, mempunyai ketahanan yang kuat relating kuat dan stabil dalam menghadapi guncangan atau turbelensi ekonomi baik dari dalam maupun luar ${ }^{3}$. Potensi FinTech syariah di Indonesia cukup besar, sebab menyediakan solusi terhadap kebutuhan yang tidak bisa dilayani oleh lembaga keuangan tradisional.

Dalam paper atau tulisan ini akan membahas dan mengkaji konsep dasar teknologi keuangan (fintech), e-commerce bagian dari konsep fintech, Faktor-Faktor penggerak FinTech, Ekonomi syariah dalam menghadapi era FinTech, perencanaan finansial dalam mengelola keuangan syariah, peluang perkembangan FinTech Berbasis Syariah, Tantangan FinTech berbasis Syariah, perkembangan fintech di Indonesia,

\footnotetext{
${ }^{1}$ Muhamad Rizal, Erna Maulina, and Nenden Kostini, "Fintech Sebagai Salah Satu Solusi Pembiayaan Bagi UMKM," AdBispreneur (2019), 90 .

${ }^{2}$ Suradi Canggih Chandriana, Rinitami Njatrijani, "Pertanggungjawaban PT Go-Jek Indonesia Terhadap Pelaksanaan Pengangkutan Penumpang," Diponegoro Law Journal (2017), 8.

${ }^{3}$ Irfan Nurfalah et al., "Early Warning to Banking Crises in the Dual Financial System in Indonesia: The Markov Switching Approach," Journal of King Abdulaziz University, Islamic Economics 31, no. 2 (2018): 133-156.
} 
implikasi serta potensi resiko FinTech yang dibawanya, diakhiri dengan penutup.

\section{Financial Technology (Fintech) atau Layanan Teknologi Keuangan}

Literatur yang ada, banyak definisi mengenai FinTech dan beragam. Arti dan tempat yang luas, FinTech mengacu pada penggunaan teknologi dalam memecahkan persoalan-persoalan keuangan ${ }^{4}$. Makna secara khusus, FinTech adalah aplikasi teknologi digital dalam memberikan solusi terkait intermediasi keuangan. Ada pula yang mendefinisikan FinTech sebagai technologically enabled financial innovation that could result in new business models, applications, processes or products with an associated material effect on financial markets and institutions and the provision of financial services" ". Maksudnya, inovasi keuangan yang dimungkinkan secara teknologi yang dapat menghasilkan model bisnis baru, aplikasi, proses atau produk dengan efek material yang terkait pada pasar dan lembaga keuangan dan penyediaan layanan keuangan.

Perkembangan FinTech pada layanan jasa keuangan digolongkan menjadi lima (5) jenis, yaitu: (1) pembayaran; (2) transfer; (3) kliring dan (4) penyelesaian seperti payment, clearing and settlement ${ }^{6}$. Kegiatankegiatan ini berhubungan erat dengan pembayaran secara mobile baik pada bank atau lembaga keuangan non-bank, dompet elektronik, uang digital dan pemakaian teknologi untuk buku besar terdistribusi.

Bentuk atau jenis model dipaparkan sebelumnya memiliki tujuan untuk meningkatkan penggunaan inklusi keuangan (financial inclusion), memastikan kemudahan konsumen dalam mengakses layanan jasa pembayaran yang lebih luas dan kegunaan sistem pembayaran yang baik. Bentuk model ini memberikan sumbangsih terhadap pengelolaan transaksi, transfer dan settlements besar antar lembaga keuangan tentang tabungan, deposito, pinjaman dan penambahan modal. Inovasi FinTech yang paling dibidan gini adalah crowdfunding dan platform pinjaman $\mathrm{P} 2 \mathrm{P}$ (peer-to-

\footnotetext{
${ }^{4}$ Muhammad Afdi Nizar, "Teknologi Keuangan (Fintech) : Konsep Dan Implementasinya Di Indonesia," Warta Fiskal 5 (2017): 1-11, https://www.researchgate.net/publication/323629323.

5 lihat http://www.fsb.org/what-we-do/policy-development/additional-policy-areas/monitoring-offintech/.

6 Budi Wibowo, “Analisa Regulasi Fintech Dalam Membangun Perekonomian Di Indonesia,” Jurnal Magister Teknik Elektro Universitas Mercu Buana (2016), 6 .
} 
peer) secara online, mata uang digital (digital currencies) dan DLT (Distrubet Ledger Technology ). Aplikasi ini terkait erat dengan intermediasi keuangan, sehingga meningkatkan eksistensi lembaga keuangan lebih mampu menghadapi kompetisi pada pasar keuangan.

\section{E-Commerce Bagian dari Fintech}

Market share atau pangsa pasar paling besar untuk FinTech yakni payment gateway termasuk e-commerce. Hasil survey menunjukkan pemakaian payment gateway sampai $60 \%$ atau memiliki nilai tertinggi daripada sektor lain pada bisnis FinTech ${ }^{7}$. Bagi pemerintah sebagai pengambil kebijakan, sangat mudah untuk mencapai cashless society (Gerakan Nasional Non Tunai). Tujuannya adalah membentuk perilaku masyarakat dalam bertransaksi mengutamakan nontunai atau digital payment ruang lingkup e-commerce dibandingkan dengan uang tunai atau kontan. Mengingat potensi kecenerungan perilaku masyarakat Indonesia yang cukup besar untuk transaksi secara daring.

Laudon mendefinisikan electronic commerce atau e-commerce sebagai penggunaan internet untuk aktivitas transaksi bisnis dengan konsumen yang meliputi World Wide Web untuk penjualan produk dan pelayanan konsumen ${ }^{8}$. Laudon dalam Maulana et al. (Maulana, Susilo, and Riyadi 2015) menggolongkan e-commerce menjadi lima, yaitu Business to Consumer (B2C), Business to Business (B2B), Consumer to Consumer (C2C), Peer to Peer (P2P), dan Mobile-Commerce (M-Commerce) ${ }^{9}$.

Karakteristik yang khas terdapat pada kelima penggolongan $e$ commerce. Misalnya untuk e-commerce yang paling besar pangsa pasarnya adalah Bussiness to Consumer (B2C). Peminat paling tinggi adalah B2C, meliputi transaksi yang sering dilakukan masyarakat seperti penjualan, pembelian dan penawaran melewati market place pada media sosial. Implikasi yang wajar sebagai akibat perkembangan financial technology, masyarakat secara sadar atau tidak telah terpengaruh kustomisasi missal, sehingga pola atau cara bertransaksinya berubah.

\footnotetext{
${ }^{7}$ Naili Saadah, "Perencanaan Keuangan Islam Sederhana Dalam Bisnis E-Commerce Pada Pengguna Online Shop,” Economica: Jurnal Ekonomi Islam (2018), 111.

8 Irma Muzdalifa, Inayah Aulia Rahma, and Bella Gita Novalia, "Peran Fintech Dalam Meningkatkan Keuangan Inklusif Pada Umkm Di Indonesia (Pendekatan Keuangan Syariah)," Masharif al-Syariah: Jurnal Ekonomi dan Perbankan Syariah (2018), 340.

9 A. Siregar, "Financial Technology Tren Bisnis Keuangan Ke Depan," Infobanknews., 2016, http://infobanknews.com.
} 
E-commerce menjadi kebutuhan pokok bagi pelaku industri dalam memenangkan kompetisi sejak revolusi industri 4.0 terjadi, karena adanya kemudahan dan kefektifannya. E-commerce merubah perilaku produsen dan konsumen saat melakukan transaksi, dari menawarkan, memasarkan, transaksi dan terjadi deal. Semua kegiatan ini dilaksankan tanpa harus bertemu muka, bisa dilakukan dimanapun tanpa ada batas waktu dan jarak - Ada banyak website e-commerce gratis yang ditawarkan, ini yang menjadi alasan para pelaku usaha ikut serta melakukan bisnis dengan media e-commerce.

\section{Faktor-Faktor Penggerak Inovasi Fintech}

Keberadaan FinTech sebenarnya dimulai dari inovasi adanya kartu kredit pada 1960-an. Pada 1970-an berkembang kartu debit dan terminal yang menyediakan uang kontan, seperti Anjungan Tunai Mandiri (ATM), pada 1980-an berkembang dengan adanya phone banking dan aneka ragam produk keuangan. Selanjutnya pada 1990-an adanya aturan mengenai pasar modal dan obligasi.Kehadiran Internet banking memicu perbankan tanpa perlu kantor cabang dan aktivitas dilaksanakan dalam jarak jauh. Selanjutnya teknologi telepon seluler memberikan kemudahan untuk bertransaksi keuangan ${ }^{10}$.

Terdapat dua faktor yang menjadi penggerak adanya evolusi dalam inovasi teknologi keuangan, yaitu: permintaan dan penawaran. Berikut faktor yang bersumber dari sisi permintaan antara lain: (1) perubahan selera konsumen terhadap inovasi; kemudahan dalam mengakses internet dan ketersediaan jaringan, mendorong adanya harapan yang tinggi terutama mengenai kenyamanan, kecepatan, biaya yang murah dan penggunaan layanan jaringan; perubahan preferensi disebabkan oleh faktor demografi, seperti kelompok keluarga, kelompok profesi dan sebagainya; (2) adanya evolusi teknologi; inovasi teknologi dalam memberikan pelayanan berkembang secara pesat dan dengan cara-cara baru dengan memanfaatkan model-model baru. Model bisnis dan aplikasi teknologi baru munculnya pemain-pemain baru dalam sektor keuangan, seperti

10 Dodi Yarli, "Analisis Akad Tijarah Pada Transaksi Fintech Syariah Dengan Pendekatan Maqhasid," Yudisia Jurnal Pemikiran Hukum dan Hukum Islami 9, no. 2 (2018). 
model bisnis dengan memakai teknologi big data, artificial intelligence, machine learning, cloud computing dan biometrics, dengan demikian untuk penerapan teknologi baru, sama sekali berbeda teknologi sebelumnya.

Sisi penawaran ialah regulasi keuangan dan struktur pasar yang terus berubah, terutama setelah krisis keuangan global 2008/2009. Perubahan ini bertujuan untuk mengurangi terjadinya resiko krisis keuangan yang sama pada masa yang akan datan, seperti ketentuan neraca, dengan mensyaratkan jumlah modal yang lebih besar dan rasio leverage yang lebih rendah pada sektor perbankan. Bertujuan meminimalisir resiko yang muncul oleh kegiatan dan entitas. Gabungan perubahan regulasi keuangan menyebabkan banyak hal yang ikut berubah. Perusahaanperusahaan keuangan konvensional, didalamnya ada bank, ditekan untuk mengurangi besaran biaya dan memakai modal secara efisien.

\section{Perkembangan Fintech di Indonesia}

Perkembangan FinTech di Indonesia yang sangat pesat akibat adanya evolusi global terkait inovasi teknologi keuangan. Ukuran untuk melihat ketersediaan konfigurasi FinTech terbatas sekali. Data yang ada, hanya menyediakan jumlah perusahaan dan market size sebagai referensi.

Berikut gambar 1, memaparkan perusahaan di Indonesia yang mempergunakan teknologi layanan sesuai sektor yang

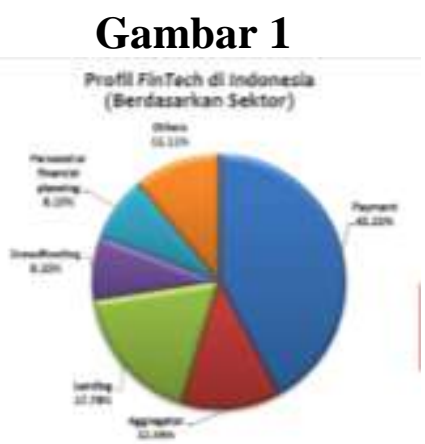

Sumber: Asosiasi FinTech dan OJK yang diolah ${ }^{11}$

\footnotetext{
${ }^{11}$ Muliaman D Hadad, "Financial Technology (FinTech) Di Indonesia” Kuliah Umum Tentang FinTech-IBS (Jakarta, 2017), 7.
} 
Gambar di atas menunjukkan bahwa pelaku bisnis FinTech di Indonesia masih didominasi sektor payment atau pembayaran sebesar $43 \%$, disusul pinjaman sebesar $17 \%$ dan sisanya crowfunding, aggregator dan sebagainya.

Grafik 1 akan diuraikan jumlah perusahaan yang bergabung dalam bisnis FinTech.

$$
\text { Grafik } 1
$$

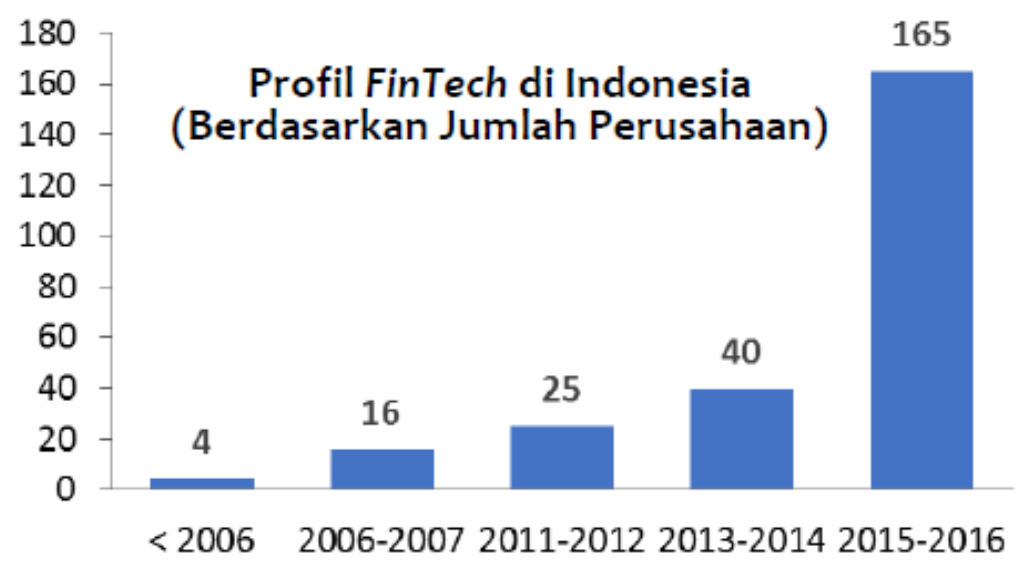

Sumber: Asosiasi FinTech dan OJK yang diolah ${ }^{12}$

Data yang disajikan pada grafik 1, menunjukkan perkembangan perusahaan yang melakukan kegiatan FinTech, diawali sebelum 2006 hanya ada 4 perusahaan. Pada 2006-2007 terjadi peningkatan sekitar $300 \%$. Pertumbuhan yang cukup spektakuler terjadi pada 2015-2016, yakni jumlah perusahaan FinTech bertambah 125 perusahaan, sebelumnya pada 2013-2015 hanya sebanyak 40 perusahaan. Artinya meningkat menjadi $312,5 \%$ jika dibandingkan tahun sebelumnya.

Tabel 2. Berisi tentang model jenis pembiayaan secara online yang ada di Indonesia.

\footnotetext{
12 ibid, 7.
} 
Tabel 2

Jenis Model Pembiayaan FinTech Indonesia,

\begin{tabular}{|c|c|c|c|c|}
\hline Model & 2013 & 2014 & 2015 & 2016 \\
\hline P2P (market place) business lending & $\checkmark$ & $\checkmark$ & $\checkmark$ & $\checkmark$ \\
\hline P2P (market place) consumer lending & & & & $\checkmark$ \\
\hline P2P (market place) real estate lending & & & & $\checkmark$ \\
\hline Donation-based crowdfunding & $\checkmark$ & $\checkmark$ & $\checkmark$ & $\checkmark$ \\
\hline Equity-based crowdfunding & & & & $\checkmark$ \\
\hline Reward-based crowdfunding & $\checkmark$ & $\checkmark$ & $\checkmark$ & $\checkmark$ \\
\hline Revenue-sharing/profit-sharing crowdfunding & & & & $\checkmark$ \\
\hline Debentures (debt-based securities) & & & & $\checkmark$ \\
\hline Balance sheet consumer lending & & & & $\checkmark$ \\
\hline
\end{tabular}

Sumber : CCAF (2017) sumber yang diolah ${ }^{13}$

Pemaparan tabel di atas, menunjukkan bahwa pada 2016 terdapat sembilan (9) jenis model pembiayaan alternatif online, antara lain: (1) Peer-to-peer (P2P)/market place business lending; (2) Peer-to-peer $(P 2 P) /$ market place consumer lending; (3) Peer-to-peer (P2P)/market place real estate lending; (4 Donation-based crowdfunding; (5) Equitybased crowdfunding; (6) Reward-based crowdfunding; (7) Revenuesharing/ profit-sharing crowdfunding; (8) Debentures (debt-based securities); dan (9) Balance sheet consumer lending. Dari sembilan jenis model tersebut 6 (enam) model diantaranya mulai diperkenalkan dalam tahun 2016 dan 3 model lainnya sudah tersedia sejak tahun 2013.

Salah satu negara dengan laju pertumbuhan pasar (market size) paling tinggi dalam pelayanan FinTech adalah Indonesia. Grafik 2, akan disajikan paparan market size FinTech dengan kurun waktu 2013-2016.

\footnotetext{
${ }^{13}$ K. et al. Garvey, "Cambridge Centre for Alternative Finance (CCAF)," in The 2nd Asia Pacific Region Alternative Finance Industry Report - Cultivating Growth (September) (London: University of Cambridge., 2017).
}

\section{el-JIZYA}


Grafik 2

Market Size FinTech di Indonesia

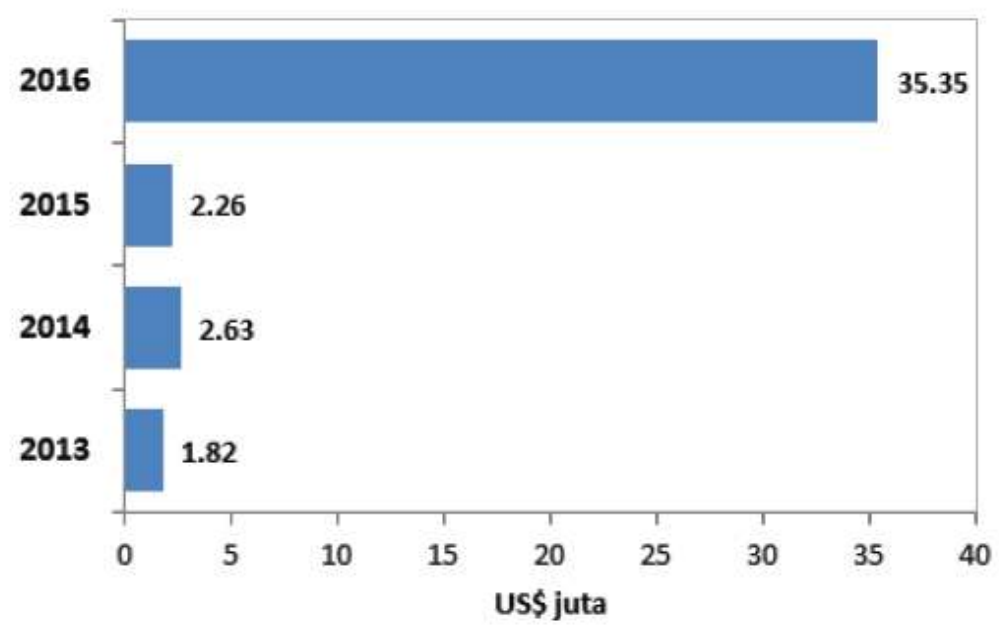

Sumber : CCAF (2017) sumber yang diolah ${ }^{14}$

Rata-rata pertumbuhan tiap tahun ukuran pasar pada jasa layanan FinTech sebesar 24,2\%. Aktivitas pembiayaan alternatif paling tinggi terjadi pada tahun 2016 meraih US\$ 35,35 juta atau setara Rp. 470,6 M. Terjadi kenaikan sebesar $1.464 \%$. Apabila dinominalkan sebesar US\$2,26juta atau Rp.30,3 Miliar.

\section{Perkembangan Ekonomi Syariah di Indonesia Yang Masif Berimbas Pada Tuntutan FinTech Berbasis Syariah}

Perbankan syarih di Indonesia telah hadir tiga dekade, meskipun pertumbuhannya tidak selaras dengan waktu yang telah dilaluinya. Pertumbuhan ekonomi syariah sampai akhir 2016 telah meraih 19. 67 persen. Pangsa pasar bank syariah mendapatkan angka 5, 12 persen, dengan total kekayaan 406, 23 triliun, pertumbuhan 19, 79\%, dana DPK 325, 96 triliun. Pembiayaan sebesar 281 triliun dengan jumlah nasabah sebanyak 24 juta jiwa. Hasil ini tidak berbanding lurus dengan potensi yang ada.

OJK (Otoritas Jasa Keuangan) terus memotivasi industri untuk melakukan sosialiasasi tentang pemahaman keuangan syariah, karena rendah. Hal ini disebabkan oleh beberapa hal yaitu suplay produk syariah

\footnotetext{
${ }^{14}$ Ibid.
} 
terbatas, akses produk atau layanan jasa keuangan syariah yang terbatas, masih belum optimal tingkat literasi keuangan syariah, sumber daya manusia terbatas, optimalisasi koordinasi dengan para pemangku kepentingan, kebijakan jasa keuangan yang selaras dan bisa saling mendukung perkembangan seluruh sektor keuangan syariah.

Pelayanan digital bangking bagi perbankan syariah menjadi sebuah kelaziman yang harus terjadi. Agar tidak sampai ditinggal pelanggannya, lembaga bisnis harus mampu menjadi pelaku perubahan, bukan sekedar sebagai penonton. Konsekwensi logisnya adalah siap dengan perubahan pola pikir (mindset), perubahan peran dan tanggungjawab atas pekerjaan barunya serta siap menghadapi persaingan dan keilmuan yang baru.

Jasa pelayanan teknologi keuangan menjadi andalan bank ialah online banking. Dengan online banking bisa menjadi value added (nilai tambah) bagi produk bank syariah. Inovasi teknologi pun mudah diakses di daerah pedesaan, sehingga bisa menjangkau keuangan mikro atau alat bantu bagi usaha kecil dan menengah. Saat ini sudah terjadi persaingan perbankan syariah yang mengarah kepada branchless banking untuk masyarakat di daerah, dengan hanya mengoptimalkan kemampuan konektivitas digital banking dengan pelanggan. Dengan demikian peluang pemanfaatan telepon seluler meningkatakn brand bank di media sosial.

\section{Perencanaan Finansial Dalam Mengelola Keuangan Syariah}

Adanya perencanaan usaha tetap diperlukan untuk memberikan kemudahan saat proses transaksi, karena penting demi keberlangsungan sebuah usaha. Kesuksesan atau kegagalan dalam berusaha bergantung pada perencanaan yang telah dibuat. Setiap usaha yang baik, tentu harus disertai perencaan yang baik pula. Perencanaan keuangan juga penting bagi usaha keci ataupun besar. Perencanaan merupakan proses pengembangan dan penerapan secara holistic dan menyeluruh dengan rancangan perencanaan buat memenuhi kebutuhan keuangan.

Dalam ekononomi Islam, perencanaan keuangan secara konsep disebut dengan istilah Islamic Financial Planning. Konsep ini merupakan bagian dari manajemen kekayaan Islam. Apabila Al-Ghazali memaparkan kesejahteraan dengan terpenuhinya lima kebutuhan dasar manusia, antara lain: agama, jiwa, akal, harta dan keturunan. Dengan demikian implementasi Islamic financial plaaning mengikuti lima kebutuhan dasar tersebut. Tiada perencanaan maka tidak mungkin tercapai pemenuhan lima kebutuhan dasar pada manusia.

\section{el-JIZYA}




\section{Peluang dan Tantangan FinTech Berbasis Syariah}

Indonesia sebagai negara populasi muslim terbesar di dunia memiliki pangsa pasar yang cukup potensial untuk pengembangan ekonomi Islam yakni posisi ekonomi kerakyatan. Bisnis dan keuangan syariah telah berkembang cepat sekali. Institusi atau lembaga keuangan syariah bermunculan antara lain perbankan syariah, asuransi syariah (takaful), koperasi syariah dan pasar modal syariah baik secara konvensional atau melalui media teknologi informatika.

Hasil survey literasi keuangan yang dilakukan OJK (Otoritas Jasa Keuangan), saat ini masih ada $40 \%$ masyarakat Indonesia belum memiliki akses langsung terhadap sektor keuangan ataupun perbankan (baik perbankan konvensional maupun syariah) ${ }^{15}$. Capaian literasi keuangan pada 2016 sebesar 8, 11\% dengan indeks inklusi sebesar 11,6\%. Ini menunjukkan masih ada peluang besar dalam pengembangan FinTech Syariah yang diikuti aturan syariah yang jelas.

Setiap perbuatan yang dilakukan manusia di dunia harus terikat dengan hukum syariah, dengan menjadikan al-Qur'an dan hadists sebagai sumber rujukannya yang telah disepakati oleh 'ulama. Sistem keuangan juga diatur berdasarkan aturan syariah, dari syarat sampai proses arus keuangan. FinTech syariah merupakan inovasi teknologi di bidang keuangan syariah seharusnya selaras dengan hukum syariah.

Kemunculan FinTech Syariah menjadikan jawaban atas persoalan mengenai sistem keuangan berbasis teknologi. Misalnya, adanya takafuli mempunyai tujuan menciptakan kepercayaan antara pemegang polis dan perusahaan asuransi. Dengan harapan yang cukup besar yaitu meningkatkan kedisiplinan yang berhubungan dengan klaim, premi berkurang dan tagihan pembayaran, digital bangking Bank Indonesia (BI) memiliki relasi dengan sistem informasi bank, ketersediaan jaringan serta edukasi dan perlindungan terhadap konsumen.

Indonesia memiliki peluang mengembangkan teknologi finansial (tekfin) syariah cukup besar yang mempunai manfaat. Bank Indonesia menganggap penting terkait aplikasi teknologi finansial dalam koridor skema Syariah yang berada dalam ruang lingkup pengembangan ekonomi syariah di Indonesia. Terdapat banyak bidang usaha yang memiliki potensi untuk digarap berbasis layanan FinTech Syariah, diantaranya kemandirian

${ }^{15}$ Rifaldi Putra irianto, Fintech Syariah, Masa Depan Keuangan Islam (2019). 
pesantren berbasis teknologi. Ada banyak produk yang berkualitas yang didapatkan oleh pesantren, FinTech syariah bisa menjadi penyedia platform kerjasama untuk saling mensuplai hasil produk antar pesantren. Pada bidang usaha lainya juga besar seperti wisata halal, FinTech berpeluang untuk memfasilitasi pembayaran ataupun pemasaran cukup besar.

Tantangan layanan FinTech berbasis syariah antara lain: kesadaran yang rendah pada masyarakat Indonesia untuk bertransaksi secara digital yakni baru 35\%; minimnya sumbangsih di sektor digital terhadap peningkatan Produk Domestik Bruto (PDB) dan para CEO bank kesulitan dalam kepemimpinan untuk mengembangkan dan melakasanakan perubahan yang menyeluruh secara simultan tentang budaya, sistem dan kemampuan yang diperlukan ${ }^{16}$.

Salah satu contoh tantangan FinTech terhadap pekembangan bisnis perbankan yaitu terkait keamanan atau sekuriti. Teknologi keamanan yang makin canggih, diikuti dengan makin canggihnya teknologi pencurian di ranah digital. Kejahatan perbankan yang sering dijumpai adalah pencurian identitas atau phising. Phising adalah pencurian data penting yang dipunyai orang lain, seperti nama lengkap, alamat tempat tinggal dan nomor telepon untuk membobol akun nasabah. Semuanya dilakukan oleh pengguna (user) sendiri tidak bertanggungjawab atas tindakan criminal berupa peretasan alamat website untuk mengambil data-data perusahaan tanpa ijin, penipuan berkedok bisnis online dan sebagainya.

\section{Implikasi dan Potensi Resiko Fintech Syariah}

Jenis alternatif model FinTech yang ada masih sedikit, tetapi keberadaannya telah memberikan warna dan implikasi terhadap layanan jasa keuangan dan berbagai pihak yang berkepentingan (perbankan, BI, OJK dan nasabah) di dalam negeri ${ }^{17}$.

Berikut beberapa implikasi dan resiko dari penggunaan FinTechn syariah, antara lain:

1. Untuk layanang keuangan, FinTech syariah berpeluang untuk memecahkan (unbundling) dan merestrukrutisasi jasa keuangan yang

\footnotetext{
${ }^{16}$ Abdus Salam, "Inklusi Keuangan Perbankan Syariah Berbasis Digital-Banking: Optimalisasi Dan Tantangan," Al-Amwal 10, no. 1 (2018): 63-80.

${ }^{17}$ Baidhowi Baidhowi, "Sharia Banking Opportunities and Challenges in the Digital Era," 2018, 158.
}

\section{el-JIZYA}


ada. Maksudnya, adanya FinTech mampu memecah fokus pada pasar keuangan. Market Share bisa terdistribusi terhadap antar pesaing untuk menawarkan jasa layanan sama. Dampaknya, tidak ada lagi lembaga perantara (intermediasi) yang dominan di pasar keuangan dan membuat harga jasa layanan keuangan turun. Adanya harga yang berubah menyebabkan konstelasi kompetisi atau persaingan berubah, karena biaya murah ${ }^{18}$. Dengan demikian membuka peluang adanya diversifikasi dan desentralisasi yang akan membuat efisiensi dalam sistem keuangan. Implikasi yang sangat penting adalah transaparansi tercipta, sehingga informasi yang asimetris bisa diminimalisir serta kemampuan pelaku pasar dalam mengelola resiko.

2. Membuka peluang seluas-luasnya bagi pelanggan baik inividu, rumah tangga dan pelaku usaha, termasuk UKM (Usaha Kecil dan Menengah) dalam mengakses jasa keuangan syariah. FinTech juga menawarkan kemudahan, kecepatan layanan dan biaya yang murah serta rasa nyaman bagi konsumen untuk menikmati layanan jasa keuangan, sehingga berimplikasi adanya manfaat dari inklusi keuangan $^{19}$. Kondisi ini diharapkan mendongkrak pertumbuhan ekonomi yang berkelanjutan, sehingga memungkinkan adanya diversifikasi eksposur terhadap resiko investasi.

3. Keberadaan FinTech syariah, memberikan kesempatan terhadap masyarakat untuk lapangan pekerjaan bagi masyarakat, memberikan kesempatan untuk melakukan investasi ${ }^{20}$.

4. Selain membawa manfaat, pemakaian FinTech berpotensi menimbulkan resiko. Resiko yang paling awal adalah resiko yang ditanggung konsumen. Diantaranya terkait keamanan data (cyber risks), privasi dan kepemilikan data, serta tata kelola (governance) data. Resiko timbul jika sistem dan proses yang berbasis komputer rentan untuk disalahgunakan oleh para hacker untuk niat kriminalitas. Resiko ini tentu berdampak terhadap operasional perusahaan FinTech,

${ }^{18}$ Handriyani Dwilita Pipit Buana Sari, "Prospek Financial Technology (Fintech) Di Sumatera Utara Dilihat Dari Sisi Literasi Keuangan, Inklusi Keuangan Dan Kemiskinan," Kajian Akuntansi (2016), 17.

${ }^{19}$ Dwi Marlina Wijayanti \& Alex Fahrur Riza, "Sharia Fintech: Positive Innovation in Consumer Perspective," in Proceeding International Seminar Academic Network on Competition Policy, $2017,115$.

${ }^{20}$ Rokhmat Subagiyo, "Daya Saing Generasi Muslim Di Era Revolusi Industri 4.0,” Dimensi (LPM Dimensi IAIN Tulungagung, 2018), 18. 
infrastruktur pasar keuangan, atau bahkan sektor-sektor yang memberikan efek sistemik pada sistem keuangan.

\section{Penutup}

Berdasarkan paparan di atas, dapat direkomendasi bahwa era FinTech sebuah keniscayaan yang tidak bisa dihindarkan, ekonomi syariah perlu menjawab tantangan FinTech dengan mengeluarkan produk atau kebijakan yang selaras dengan perkembangan FinTech serta tidak bertentangan dengan prinsip-prinsip syariah.

Teknologi informasi berkembang sangat pesat bisa membantu mewujudkan tujuan dengan menjadikannya sebagai fasilitas yang efektif untuk memperluas akses pasar perbankan syariah. Peran dan fungsi bank syariah lebih dari sekedar relasi antara debitur dan kreditur, tetapi terjadi hubungan kemitraan antara shohibul maal dan mudharib yang berdampak kepada kesejahteraan kedua belah pihak.

Dengan online banking menjadi value added terhadap layanan perbankan syariah. Digitalisasi perbankan syariah akan mempermudah dalam menyimpan dan menganalisis data nasabah, sehingga membantu perbankan untuk menjaga hubungan dengan nasabah, mengatasi keluhan konsumen dengan cepat, efisien dan efektif. Digital banking selain memberikan manfaat, terdapat hambatan dan tantangan, diantaranya mahalnya biaya, infrastruktru yang terbatas, sampai tindak kejahatan perbankan oleh user itu sendiri. 


\section{Daftar Rujukan}

Baidhowi, Baidhowi. "Sharia Banking Opportunities and Challenges in the Digital Era," 2018.

Canggih Chandriana, Rinitami Njatrijani, Suradi. "Pertanggungjawaban

PT Go-Jek Indonesia Terhadap Pelaksanaan Pengangkutan Penumpang." Diponegoro Law Journal (2017).

Dwi Marlina Wijayanti \& Alex Fahrur Riza. "Sharia Fintech: Positive Innovation in Consumer Perspective." In Proceeding International Seminar Academic Network on Competition Policy, 2017.

Garvey, K. et al. "Cambridge Centre for Alternative Finance (CCAF)." In The 2nd Asia Pacific Region Alternative Finance Industry Report Cultivating Growth (September). London: University of Cambridge., 2017.

Hadad, Muliaman D. "Financial Technology (FinTech) Di Indonesia." Jakarta, 2017.

Irianto, Rifaldi Putra. Fintech Syariah, Masa Depan Keuangan Islam 
(2019).

Muzdalifa, Irma, Inayah Aulia Rahma, and Bella Gita Novalia. "Peran

Fintech Dalam Meningkatkan Keuangan Inklusif Pada UMKM Di Indonesia (Pendekatan Keuangan Syariah)." Masharif al-Syariah: Jurnal Ekonomi dan Perbankan Syariah (2018).

Nizar, Muhammad Afdi. "Teknologi Keuangan (Fintech) : Konsep Dan Implementasinya Di Indonesia." Warta Fiskal 5 (2017): 1-11. https://www.researchgate.net/publication/323629323.

Nurfalah, Irfan, Aam Slamet Rusydiana, Nisful Laila, and Eko Fajar Cahyono. "Early Warning to Banking Crises in the Dual Financial System in Indonesia: The Markov Switching Approach." Journal of King Abdulaziz University, Islamic Economics 31, no. 2 (2018): 133156.

Pipit Buana Sari, Handriyani Dwilita. "Prospek Financial Technology (Fintech) Di Sumatera Utara Dilihat Dari Sisi Literasi Keuangan, Inklusi Keuangan Dan Kemiskinan.” Kajian Akuntansi (2016).

Rizal, Muhamad, Erna Maulina, and Nenden Kostini. "Fintech Sebagai Salah Satu Solusi Pembiayaan Bagi UMKM.” AdBispreneur (2019).

Saadah, Naili. "Perencanaan Keuangan Islam Sederhana Dalam Bisnis ECommerce Pada Pengguna Online Shop." Economica: Jurnal Ekonomi Islam (2018).

Salam, Abdus. "Inklusi Keuangan Perbankan Syariah Berbasis DigitalBanking : Optimalisasi Dan Tantangan.” Al-Amwal 10, no. 1 (2018): 63-80.

Siregar, A. "Financial Technology Tren Bisnis Keuangan Ke Depan." Infobanknews., 2016. http://infobanknews.com.

Subagiyo, Rokhmat. "Daya Saing Generasi Muslim Di Era Revolusi Industri 4.0.” Dimensi. LPM Dimensi IAIN Tulungagung, 2018.

Wibowo, Budi. "Analisa Regulasi Fintech Dalam Membangun Perekonomian Di Indonesia." Jurnal Magister Teknik Elektro Universitas Mercu Buana (2016).

Yarli, Dodi. "Analisis Akad Tijarah Pada Transaksi Fintech Syariah Dengan Pendekatan Maqhasid." Yudisia Jurnal Pemikiran Hukum dan Hukum Islami 9, no. 2 (2018).

"No Title," n.d. http://www.fsb.org/what-we-do/policydevelopment/additional-policy-areas/monitoring-of-fintech/. 
Rokhmat Subagiyo: Era Fintech Peluang Dan Tantangan....(316-336) 